\title{
Detecting deceased patients on remote monitoring: a case series.
}

\author{
Christopher Monkhouse $^{1}$, Clare Rochford ${ }^{1}$, Ciaran Goswell ${ }^{1}$, Angela Hawkins ${ }^{1}$, Russell \\ Moralee $^{1}$, Emma Dooley ${ }^{1}$, Anthony $\mathrm{Chow}^{2}$, and Simon Sporton ${ }^{3}$ \\ ${ }^{1}$ Barts Health NHS Trust \\ ${ }^{2}$ Barts and The London NHS Trust \\ ${ }^{3}$ Barts Heart Centre, St Bartholomew's Hospital
}

October 29, 2020

Detecting deceased patients on remote monitoring: a case series.

Christopher Monkhouse BSc CCDS, Clare Rochford BSc CCDS, Ciaran Goswell BSc CCDS CCEPS, Angela Hawkins BSc CCDS, Russell Moralee BSc, Emma Dooley BSc CCDS, Anthony W Chow MB BS BSc MD FRCP, Simon Sporton BSc MB BS MD FRCP

All authors from: Barts Heart Centre, West Smithfield, London, EC1A 7BE, UK

Corresponding author:

Christopher Monkhouse

Barts Heart Centre, West Smithfield, London, EC1A 7BE, UK

c.monkhouse@nhs.net

$+442034655855$

Word Count: 1366

Short Title: Deaths on remote monitoring

Conflicts of interest:

CM has received speaker fees from Abbott, Boston Scientific, Biotronik \& Medtronic

AWC has received grant fees from Abbott

Keywords: death, remote monitoring, telemedicine, ambulance, police

Introduction :

Remote monitoring of implantable cardiac devices provides a wealth of information about device function, arrhythmia and devices therapies. The ever-increasing number of device patients on remote monitoring presents a challenge for device services in terms of both the volume and nature of information received. A notable example of the latter is a transmission demonstrating a life-threatening arrhythmia without evidence of successful treatment. Although most departments triage alerts using remote monitoring platforms there is no specific alert for a potentially deceased patient: this must be established by the practitioner reviewing the transmission.

As a tertiary cardiac centre with over 5000 patients on remote monitoring, with approximately $75 \%$ being defibrillator (ICD) patients, $5 \%$ pacemaker and $20 \%$ implantable loop recorder patients, producing over 40 alert transmissions per day, which are reviewed by Cardiac Scientists with medical review if medical 
management is required. Forty three percent of patients are enrolled on Latitude (Boston Scientific), 36\% on Carelink (Medtronic), 16\% on Merlin (Abbott) and 5\% on Cardiomessenger (Biotronik). We describe thirteen deaths that were detected via cardiac remote monitoring, highlight key features of a transmission pointing to the likely diagnosis, discuss the implications for device services and propose a management strategy for such scenarios.

Case Summaries :

Described in Table 1

Results

Thirteen deceased patients were detected by via remote monitoring platforms during a six-year period between 2014 and 2020. In 7/13 (54\%) of these cases the patient's death was already known, either by patient's family or hospital systems. Most patients had defibrillators 10/13 (77\%) and transmissions were commonly seen during the weekend, $9 / 13(69 \%)$. Alerts were received for Ventricular tachycardia (VT) or Ventricular Fibrillation (VF) events 9/13 (70\%), right ventricular lead integrity 3/13 (23\%) implantable loop recorder (ILR) device at elective replacement indicator $1 / 13(8 \%)$.

Of the patients that died of VT/VF events: 6 patients had exhausted all therapies with shocks being successful at cardioverting arrhythmia, however, arrhythmia was reinitiated almost immediately after therapies. Three patients did not receive therapy for VT/VF that was significantly below the programmed ICD therapy zones and observed as non-sustained VT recordings.

Remote transmission features indicating death

Several diagnostic features may indicate death. These are summarised in table 2.

In our experience that the most specific diagnostic feature is the presenting electrogram (EGM) transmission. Electrograms (EGMs) demonstrating pacing at the lower rate limit with no evoked response or local capture on intracardiac EGM and no $\mathrm{T}$ waves across any channel (particularly far field) suggest the absence of myocardial capture (figure 1). In addition, the EGM gain will also be increased to maximum as the device attempts to detect any EGMs, which are absent in asystole. An agonal rhythm could present similarly with or without pacing, however, we did not observe this within our cohort of patients. Notably, not all remote monitoring platforms produce a presenting EGM, Biotronik Home Monitoring requires scheduled transmissions to transmit a presenting EGM.

Device diagnostics and lead parameters are another potentially useful indicator of a deceased patient. An increase in intracardiac impedance is a known phenomenon post-mortem, although the measured value can be still within normal limits ${ }^{1,2,3,4}$. Threshold values from automated tests will be suspended or appear high, as there is no capture. Sensing values would not be recordable post-mortem.

Arrhythmia events recorded by the device may be an indication of death, particularly if they show exhausted therapies or agonal rhythms. However, patients who have had arrhythmias below detection or of a nonarrhythmic cause may not present with arrhythmia EGMs.

Death is not the only explanation for these observations. A device that has been explanted and kept by the patient on request, but not disconnected from the remote monitoring platform, can transmit with all the above features. This situation happened at our centre, where a patient received a heart transplant from another centre as an emergency, stored his old device in his bedside draw, led to an emergency alert before this was discovered. One further differential is a fracture of the device header or pin attachment. However, this is likely be accompanied by EGMs demonstrating fracture potentials.

\section{Discussion}

To the best of our knowledge this is the first case series to demonstrate the ways in which death may be detected by cardiac remote monitoring. Previous literature has been limited to single case reports ${ }^{1,2,3}$. 
In our series the most common alert transmission from a deceased patient was for VT/VF and shock therapy delivered, consistent with the observation that ventricular fibrillation is the first monitored rhythm in a majority of out-of-hospital cardiac arrests ${ }^{5}$. This was triaged as either a yellow or a red alert by different manufacturers' remote monitoring platforms due to disparities between manufacturers' programmable alert settings and the information that is received from a device. Centres should be aware of these when triaging remote monitoring all patients; for example, there is no presenting EGM transmitted by Biotronik remote monitoring alert transmissions and Medtronic Carelink does not have an alert for ATP-only episodes. These can be important indicators that a patient has died.

The second most frequent deceased patient alert transmission in our series was due to abnormal lead measurements. This alert is more likely if the ICD therapy has not been delivered either due to a lethal ventricular tachyarrhythmia occurring when tachycardia therapies are disabled, VT/VF falling below the programmed tachycardia detection limit or in the unlikely event of sudden pulseless electrical activity or primary asystole. Practitioners should be aware that a rise in impedance is dependent on the time of death ${ }^{1,3}$. A post-mortem impedance rise can be seen as a significant change from previous measurements but remain within normal range. Automatic threshold tests can also be suggestive of death, as threshold will not be able to be measured. This phenomenon is seen when programmed and if lead measurements are attempted by the device post-mortem.

One patient with an implantable loop recorder (ILR) transmitted with the longest delay (28 days) to transmission due to battery at ERI. An ongoing pause episode does not prompt an alert transmission because ILRs are unable to end a pause if there is not a second $\mathrm{R}$ wave. The mechanism of death for this patient could not be determined by post-mortem examination. As the increasing burden on ILR and other forms of monitoring (e.g. pulmonary artery pressure monitoring) increases worldwide, this phenomenon will not be limited to pacemakers and defibrillators. With ILR devices the differential of device protrusion could cause loss of sensing with similar diagnostics. This should be investigated by contacting the patient to determine the cause.

In our series, transmissions post-mortem showed a preponderance for the weekend. We have been conducting a 7-day remote transmission-review service since 2016 due to the sheer number of alerts that occurred over the weekend. However, this is not the norm for most device services or the standard from HRS guidance for cardiac monitoring services and a delay would have had no clinical consequence ${ }^{6}$.

As remote monitoring currently comprises a once-daily transmission of alert events the chance of providing life-saving therapy is minimal. Same-day investigation of a potentially deceased patient detected by remote monitoring should therefore not be considered mandatory as it is unlikely to result in life-saving treatment. Nevertheless, one of our patients with a presenting EGM of VF was undergoing cardio-pulmonary resuscitation by care home staff when they were contacted by us. Their efforts were, unfortunately, unsuccessful. The development of remote monitoring using mobile devices, able to transmit live data to hospitals, could provide services with logistical challenges and have medico-legal implications.

We suggest that centres undertaking remote cardiac monitoring should have a Standard Operational Policy outlining the device alerts that they will activate for each specific device manufacturer, the frequency of review of remote transmissions, including those made at weekends and the response to specific alerts and transmission findings indicating the possibility of death (Figure 2). We also suggest that the institution's legal service should be consulted during policy development.

\section{Conclusion}

Recent years have seen rapid expansion of remote monitoring of cardiac rhythm management devices, presenting logistical, ethical and, potentially legal challenges. Death detected by remote monitoring is an unusual event. We have described the characteristics of alert transmissions indicating the possibility of death and propose a strategy for the immediate management of this situation.

References 
1. Nayeri AN, Pavri BB. Abrupt increase in impedance measurements as detected via remote monitoring: What is the cause? Heart Rhythm case reports. 2015;1(2):51-3. 2. Schaer B, Kühne M, Osswald S, Sticherling C. Remotely monitored death of a patient with implanted ICD. Pacing Clin Electrophysiol. 2012;35(9):e280-3. 3. Stroobandt RX, Van Heuverswyn FE, Kucher A, Barold SS. Rise in ICD Shock Impedance: Lead Fracture or Death? Pacing and Clinical Electrophysiology. 2012;35(9):1103-10. 4. Grubman EM, Pavri BB, Shipman T, Britton N, Kocovic DZ. Cardiac death and stored electrograms in patients with third-generation implantable cardioverter-defibrillators. Journal of the American College of Cardiology. 1998;32(4):1056-62. 5. Poole JE, Bardy GH. Sudden Cardiac Death. Chapter 73 in Cardiac Electrophysiology: from Cell to Bedside. Eds Zipes DP and Jalife J. WB Saunders 1995. 6. Slotwiner D, Varma N, Akar JG, Annas G, Beardsall M, Fogel RI, et al. HRS Expert Consensus Statement on remote interrogation and monitoring for cardiovascular implantable electronic devices. Heart Rhythm. 2015;12(7):e69-e100.

Table 1. Summaries of individual cases. Key. CRT: Cardiac resynchronisation, P/PPM: pacemaker, D: Defibrillator, DR: dual chamber, ICD: implantable cardioverter defibrillator, ILR: implantable loop recorder, VR: single chamber, ERI: elective replacement indicator, RV: right ventricular, VT: Ventricular Tachycardia, VF: Ventricular fibrillation

Figure 1. Medtronic DR ICD showing asystole with no evoked response on the near field channel, no T wave on any channel and all EGM gains have been increased to maximum.

Figure 2. Flow diagram for management of a potentially deceased patient.

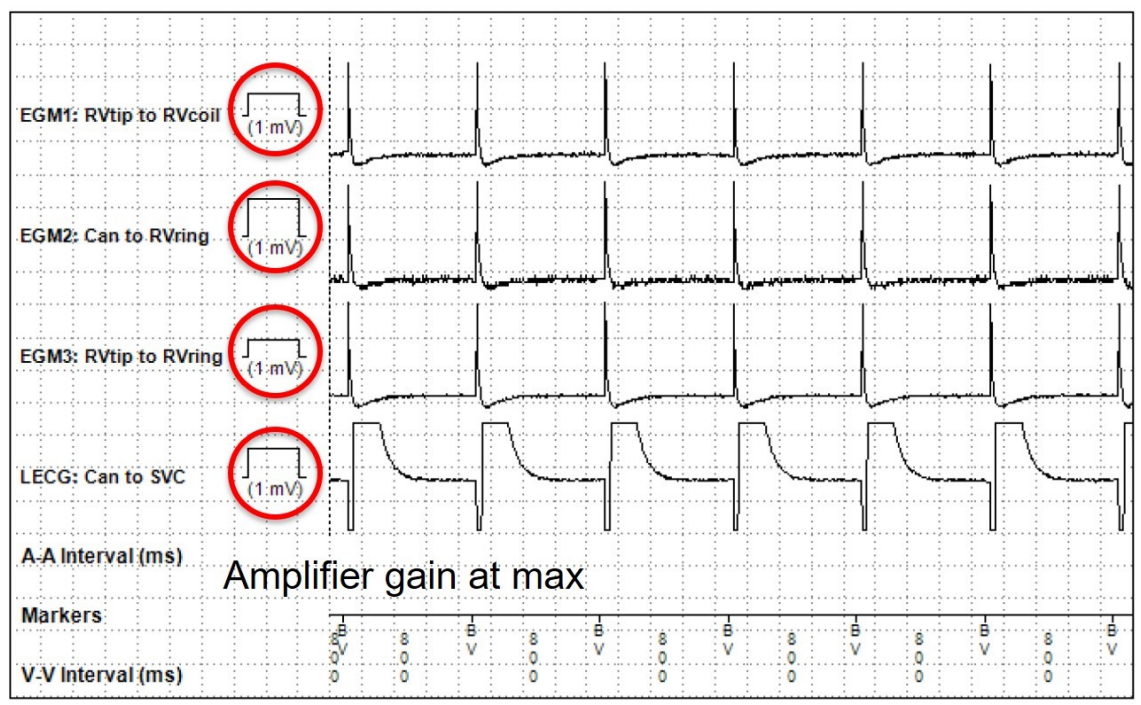




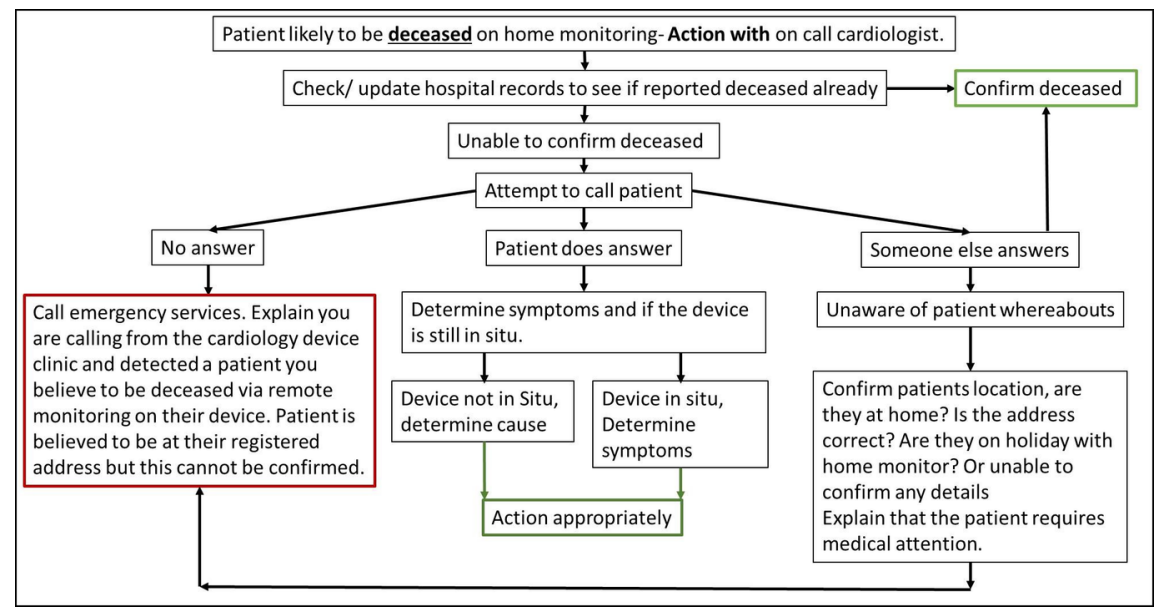

\begin{tabular}{|c|c|c|c|c|c|c|c|c|c|c|c|c|c|c|c|c|c|}
\hline paraient. & Age Device type & Aetiology & $\begin{array}{l}\text { Lett } \\
\text { venticalat } \\
\text { section } \\
\text { Fratrion }\end{array}$ & $\begin{array}{l}\text { Electrocerdio } \\
\text { graphicition } \\
\text { incication }\end{array}$ & $\begin{array}{l}\text { Ssmprom } \\
\text { indicaton }\end{array}$ & 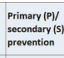 & i) urra casss & $\begin{array}{l}\text { Other medical } \\
\text { conditions }\end{array}$ & Day received & $\begin{array}{l}\text { Trime to } \\
\text { reviow }\end{array}$ & $\begin{array}{l}\text { Alert } \\
\text { transmission }\end{array}$ & V/U E events: & is shocks & $\begin{array}{l}\text { ks Likely cause } \\
\text { of d death }\end{array}$ & $\begin{array}{l}\text { Call from } \\
\text { hospital } \\
\text { onswered }\end{array}$ & $\begin{array}{l}\text { Ambulance } \\
\text { callod }\end{array}$ & $\begin{array}{l}\text { - Coroner's } \\
\text { investigstion }\end{array}$ \\
\hline & 80 CRT-P & 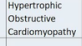 & & 50\% None & Dysperea & N/A & "I" & $\begin{array}{l}\text { Oiaberes, } \text {,ypertension, } \\
\text { Spinal discose }\end{array}$ & Sunday & odays & $\begin{array}{l}\text { Yellow- vT } \\
\text { episode reorded }\end{array}$ & yes & $N / A$ & UT/NF & $\begin{array}{l}\text { fomily } \\
\text { conftrmed } \\
\text { death } \\
\text { deative }\end{array}$ & No & No \\
\hline & $G 6$ CRT-D & $\begin{array}{l}\text { schemic } \\
\text { carclonyopattly }\end{array}$ & & 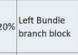 & $\begin{array}{l}\text { Dysereas } \\
\text { olizy spels }\end{array}$ & s & "1/III & $\begin{array}{l}\text { Diabses, } \\
\text { Hyyoutyoldism }\end{array}$ & Sunday & odays & $\begin{array}{l}\text { Ree- Shock } \\
\text { delvered }\end{array}$ & Yes & Yes & VTNF & 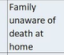 & Yes & No \\
\hline & 76 CRT-D & $\begin{array}{l}\text { schemic } \\
\text { carclompopatty }\end{array}$ & & $\begin{array}{l}30 \% \text { Left Bunde } \\
\text { branch b brck }\end{array}$ & Dssprea & s & " & 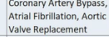 & Tuestar & odays & 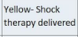 & yes & Yes & UNF & No answer & res & res \\
\hline & 73 Oค ICD & $\begin{array}{l}\text { schemic } \\
\text { Carclonvopattiv }\end{array}$ & & 24\% None & $\begin{array}{l}\text { Dysereas } \\
\text { Dlizrs sels }\end{array}$ & s & "' & Hypertension & Sunday & odays & $\begin{array}{l}\text { Red- Shock } \\
\text { delvered }\end{array}$ & yes & res & UTNF & $\begin{array}{l}\text { cate home } \\
\text { calked } \\
\text { ambualance }\end{array}$ & No & No \\
\hline & 71 OR КCD & $\begin{array}{l}\text { sithentic } \\
\text { cardionyopatthy }\end{array}$ & & 328, None & 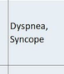 & s & "1/1" & 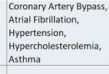 & suncay & o days & $\begin{array}{l}\text { Rede- Rvlead } \\
\text { integrity }\end{array}$ & yes & no & UTNF & No a nswer & res & No \\
\hline & 73 LR & Unkrown & & 55\% None & snicope & N/A & ' & Epilessy & Tuesder & 28 dars & Yelow- ERI & None & $N / A$ & Assytole & 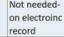 & no & No \\
\hline & 62 OA ICD & $\begin{array}{l}\text { oliated } \\
\text { Cartiomyopatity }\end{array}$ & & 255\% None & snmope & s & " & $\begin{array}{l}\text { Diaboses, } \text {, Hpertension, } \\
\text { spinal disease }\end{array}$ & "seturdar & 2 days & 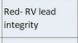 & None & No & Asystole & $\begin{array}{l}\text { family } \\
\text { contrimed } \\
\text { death }\end{array}$ & No & Yes \\
\hline & 79 CRT-D & $\begin{array}{l}\text { schlamic } \\
\text { cardionyopattiv }\end{array}$ & & $\begin{array}{l}\text { 155\% left Burcle } \\
\text { branch block }\end{array}$ & $\begin{array}{l}\text { Dyygrea, } \\
\text { olizys spels }\end{array}$ & s & "'I & Atrial Fbillatotion & Soturdar & oddys & $\begin{array}{l}\text { Yellow-Shock } \\
\text { therapy delivered }\end{array}$ & yes & Yes & VTNF & No onswer & Yes & No \\
\hline & 48 VR ICD & 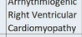 & & 15\% None & Dysereas & p & "' & 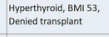 & Soturday & odys: & $\begin{array}{l}\text { Reed-ry lead } \\
\text { integegity }\end{array}$ & yes & No & UTNF & No o nswer & ves & No \\
\hline & 59 OR ICD & $\begin{array}{l}\text { Scchenic } \\
\text { carciomropattly }\end{array}$ & & $\begin{array}{l}155 \% \text { Left Buncle } \\
\text { brench blbck }\end{array}$ & Dyspreas & s & " & $\begin{array}{l}\text { Diaberes, Peripheteal } \\
\text { vascour Disesse }\end{array}$ & stutudy & odays & $\begin{array}{l}\text { Red- Shock } \\
\text { delivered }\end{array}$ & yes & yes & UTNF & $\begin{array}{l}\text { family } \\
\text { conitimed } \\
\text { death }\end{array}$ & No & No \\
\hline & ग लRा-D & $\begin{array}{l}\text { Schemenk } \\
\text { carriomyopathy }\end{array}$ & & $\begin{array}{l}255 \% \text { beft Burcale } \\
\text { brench block }\end{array}$ & Dysprea & $p$ & " & $\begin{array}{l}\text { Dibbetes, Hrpertension, } \\
\text { Coronary artery Bypass }\end{array}$ & Tuscsay & odays & 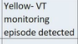 & yes & No & UTrNe & Mo a nswer & res & No \\
\hline & $=65$ OR ICD & $\begin{array}{l}\text { screnamic } \\
\text { Cardianyopatity }\end{array}$ & & 19\% None & Dyspenea & p & " & 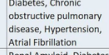 & Tuessay & odays & $\begin{array}{l}\text { Real. Shocer } \\
\text { deliverad }\end{array}$ & Yes & Yes & UTNE & No a nswer & Yes & No \\
\hline 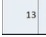 & 75 OR PPM & $\begin{array}{l}\text { Anylod } \\
\text { carclomyopatity }\end{array}$ & & $40 \%$ Motiz 1 & Dissorea & N/A & n & 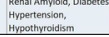 & Sundav & odars & $\begin{array}{l}\text { Yellow- vi } \\
\text { eplsode recorded }\end{array}$ & yes & N/A & UTNF & 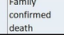 & No & No \\
\hline
\end{tabular}

